Egyptian Journal of Aquatic Biology \& Fisheries

Zoology Department, Faculty of Science,

Ain Shams University, Cairo, Egypt.

ISSN $1110-6131$

Vol. 24(1): 203 - 215 (2020)

www.ejabf.journals.ekb.eg

\title{
Genetic variation of Diplodus sargus and Diplodus vulgaris in four Mediterranean coastal regions of Egypt based on microsatellites
}

\author{
Engy T. Megahed ${ }^{1 *}$, Eman M. Abbas ${ }^{1}$, Abeer F. El Nahas ${ }^{2}$, Shabaan A. Hemeda ${ }^{2}$ \\ ${ }^{1}$ Genetics Laboratory, Aquaculture Division, National Institute of Oceanography and Fisheries \\ (NIOF), Kayed Bey, Anfushi, Alexandria, Egypt \\ ${ }^{2}$ Department of Animal Husbandry and Animal Wealth Development. Faculty of Veterinary \\ Medicine. Alexandria University. Egypt \\ "Corresponding Author: engy-tarek@hotmail.com
}

\section{ARTICLE INFO}

Article History:

Received: Nov. 4, 2019

Accepted: Dec. 30, 2019

Online: Jan.2, 2020

Keywords:

Microsatellites

Cross-species

amplification

Diplodus sargus

Diplodus vulgaris

Sparidae

Mediterranean Sea

\section{ABSTRACT}

The use of microsatellite is important for determination of regional patterns of genetic connectivity between marine populations which is necessary for proper geographical scale setting. The objective of this study is to employ cross-species primers from Sparus aurata in D. sargus and D. vulgaris in four Mediterranean coastal regions of Egypt for studying their genetic diversity, population differentiation in nearby regions.

Four microsatellite markers (SaI10, SaI12, SaI19 and SaI21) were used among 112 Diplodus sargus and Diplodus vulgaris species. The samples represented four Mediterranean coastal regions located from $31.22^{\circ} \mathrm{N}$ to $31.62^{\circ} \mathrm{N}$ and from $29.88^{\circ} \mathrm{E}$ to $30.85^{\circ} \mathrm{E}$. Variable levels of genetic diversity were observed in the four studied regions, SaI19 locus had no heterozygosity in all populations, and better heterozygosity was observed in all loci with SaI10 and SaI21 in D. sargus and D. vulgaris respectively. A low level of variation in both fishes among the four regions was observed amounting to $5 \%$ in D. sargus and $8 \%$ in D. vulgaris. Meanwhile, higher levels of variation between individuals within populations were observed amounting to $56 \%$ in D. sargus and $71 \%$ in D. vulgaris. In this study the levels of genetic variability observed in $D$. sargus $(0.048)$ and in $D$. vulgaris (0.078) were lower than those observed in other Sparidae fishes assessed with microsatellites.In conclusion, three microsatellite loci (SaI10, SaI12, and SaI21) can be applicable in D. sargus and D. vulgaris and could be used in other species of family Sparidae.

\section{INTRODUCTION}

Diplodus sargus (White seabream) and Diplodus vulgaris (the common two-banded seabream) are commercially important fish species, belonging to Sparidae family. The Diplodus genus is the largest of family Sparidae, containing 23 species (e.g., D. sargus, D. vulgaris, D. annularis, D. cervinus, D. noct, D. puntazzo) (Fishbase, 2016). They are distributed in the Eastern Atlantic Ocean and along the Mediterranean Sea (Whitehead $\boldsymbol{e t}$ 
al., 1986; Fischer et al., 1987). Many authors reported different features of their ecology and biology (Rosecchi, 1987; Garcia and Macpherson, 1995; Macpherson et al., 1997; Macpherson, 1998; Vigliola and Harmelin-Vivien, 2001), reproduction (Morato et al., 2003; Pajuelo and Lorenzo, 2004) and feeding habits (Zander and Sötje, 2002). Environmental conditions of Sparidae have also been studied by Planes et al., (1997) and Lloret and Planes (2003), where they showed that they are omnivorous fish, prefer small molluscs and crustaceans, and would also consume algae and small corals. Marine environment at the Mediterranean tends not to have major distinguished boundary lines with homogeneous marine species, nevertheless, it still shows varying levels of population differentiation (Bianchi and Morri, 2000).

Several techniques were used for the identification of fish species of family Sparidae, including morphological traits (Whitehead et al., 1986), amylase activity present in the gut of different fish species (Fernández et al., 2001), allozymes variation (Alarcón and Alvarez, 1999). DNA sequence analysis, isoelectric focusing (IEF) of water-soluble proteins and Single strand conformation polymorphism (SSCP) were also used (Schiefenhövel and Rehbein, 2013). DNA Inter-Simple Sequence Repeat (ISSR) markers were also used for the identification of Diplodus spp. (Casu et al., 2009). Moreover, random amplified polymorphic DNA (RAPD) method, was used in this area (Ali et al., 2004). The application of restriction fragment length polymorphism (RFLP) was applied to distinguish between many fish species (Cocolin $\boldsymbol{e t}$ al., 2000). DNA barcoding was applied to Family Sparidae (Armani et al., 2015; Abbas et al., 2017, 2018). Phylogeography and genetic structure have been genetically studied in several species of genus Diplodus (Planes and Lenfant, 1996; González-Wangüemert et al., 2007; Kaouèche et al., 2011; Mercedes González-wangüemert et al., 2011; El-deeb et al., 2014; Abbas et al., 2017, 2018).

Microsatellites, is another important genetic marker related to the evolution of ecology and natural systems. Microsatellites are simple sequence repeats (SSRs) that consist of 2-6 nucleotides long (Field and wills, 1996). These markers are important for the recognition of individuals, parentage and also for detecting mating success in multifarious breeding systems, as in Sparidae family (Brown et al., 2005). He used six new microsatellite markers in Sparus aurata and cross-species amplification within the Sparidae family in Greece. Also, Roques et al., (2007) characterized nine polymorphic microsatellite markers in Diplodus vulgaris and Diplodus sargus in western Mediterranean Sea. Additionally, Pérez et al., (2008) identified another eight microsatellite markers and used them in wild population of Diplodus sargus from Spain.

Cooke et al., (2016) estimated 810-11,692 km broad confidence intervals for the spatial scale gene flow at marine fish communities needed for a meaningful evolution, nevertheless, they also added that short distances could also be matter for some particular taxa. Additionally, Planes and Lenfant (1996); González-Wangüemert et al., (2004, 2007); Pérez-Ruzafa et al., (2006) detected a significant differentiation between white sea bream population at different spatial ranged from 101-103 km which is similar to values found between populations separated by $10^{2} \mathrm{~km}$. However, Roques $\boldsymbol{e t}$ al., (2007) suggested that, analysis of genetic populations' by using microsatellite is important for determination of regional patterns of genetic connectivity between marine populations which is necessary for proper geographical scale setting. 
Therefore, the goal of the present work was to employ cross-species primers from Sparus aurata in D. sargus and D. vulgaris in four Mediterranean coastal regions of Egypt for studying their genetic diversity, population differentiation in nearby regions.

\section{MATERIALS AND METHODS}

\section{Samples collection and identification}

Diplodus sargus and Diplodus vulgaris were collected from four different locations in Egypt. These locations are Lake Burullus $\left(31.62^{\circ} \mathrm{N}, 30.85^{\circ} \mathrm{E}\right)$ Bahari $\left(31.22^{\circ} \mathrm{N}, 29.88^{\circ}\right.$ E), Abo Qir $\left(31.31^{\circ} \mathrm{N}, 30.09^{\circ} \mathrm{E}\right)$ and Rashid $\left(31.51^{\circ} \mathrm{N}, 30.34^{\circ} \mathrm{E}\right)$. The map of the study area was shown in Figure1.

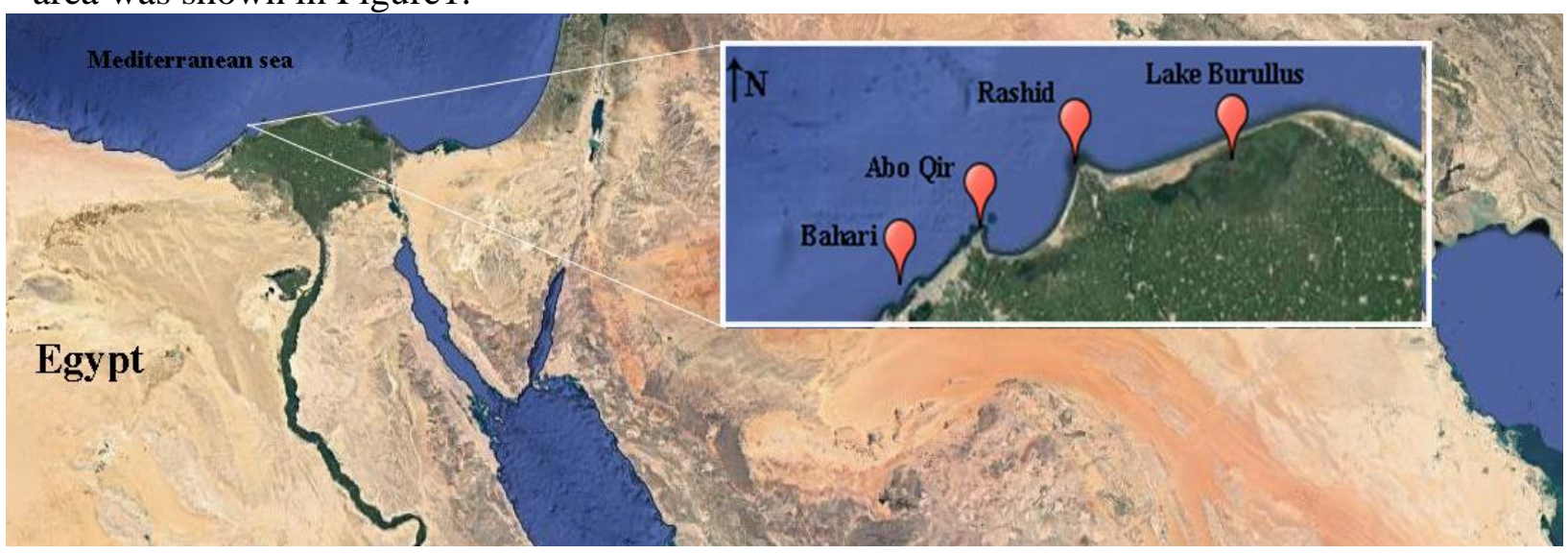

Figure 1. The map of the study area was accessed from http://www.gmapgis.com

\section{Amplification of microsatellites}

Genomic DNA was extracted from muscles of 112 fish (56 fish samples from D.sargus and 56 fish samples from D. vulgaris) by Phenol-Chloroform technique (Fan and Gulley, 2001; Cseke et al., 2011; Zhou et al., 2015). DNA was used for the amplification of four microsatellite markers by using SaI10, SaI12, SaI19 and SaI21 primers (Brown et al., 2005).

The primer sequences of these four microsatellite markers with their annealing temperature, GenBank accession numbers and their length of repeats were shown in Table 1. Total PCR volume was $10 \mu \mathrm{l}$, consisting of: $20 \mathrm{ng}$ genomic DNA template, 0.75 $\mu$ mole $(0.4 \mu \mathrm{l})$ forward and reverse primers, $5 \mu$ l Bioline MyTaq ${ }^{\mathrm{TM}}$ Red master mix. PCR amplification was performed at a temperature ranged from $60{ }^{\circ} \mathrm{C}$ to $62{ }^{\circ} \mathrm{C}$, and the exact annealing temperature $\left(\mathrm{T}_{\mathrm{a}}\right)$ for each locus were listed in Table 1 . The reactions were done in Applied Biosystems verity 96 wells thermal cycler using the following programme: initial denaturation at $95{ }^{\circ} \mathrm{C}$ for $3 \mathrm{~min}$, followed by 30 cycles of $50 \mathrm{~s}$ at $95{ }^{\circ} \mathrm{C}, 50 \mathrm{~s}$ at the corresponding primer $\mathrm{T}_{\mathrm{a}}$ and $1 \mathrm{~min}$ at $72{ }^{\circ} \mathrm{C}$; a final extension for $7 \mathrm{~min}$ at $60{ }^{\circ} \mathrm{C}$. Gel electrophoresis was performed according to (Surzycki, 2000). The gel was visualized and photographed by the Gel Documentation system (GelStudio Digital Compact, Biometra, UK). 
Table 1. Primer sequences of four microsatellite markers, annealing temperature, GenBank accession number and their repeat structure.

\begin{tabular}{lllll}
\hline $\begin{array}{l}\text { Locus } \\
\text { name }\end{array}$ & $\begin{array}{l}\text { Repeat } \\
\text { structure }\end{array}$ & Primer sequence $\left(\mathbf{5}^{\prime}-\mathbf{3}^{\prime}\right)$ & $\begin{array}{l}\text { Anneali } \\
\text { ng } \\
\text { Temp. }\end{array}$ & $\begin{array}{l}\text { GenBank } \\
\text { accession } \\
\text { no. }\end{array}$ \\
\hline SaI10 & $(\mathrm{GT})^{37}$ & $\begin{array}{l}\text { F: TCACGGGGGACCAAGACTG } \\
\text { R:CTCACACTGCCTAATTAGCACAGA }\end{array}$ & $62{ }^{\circ} \mathrm{C}$ & AY322107 \\
\hline SaI12 & $(\mathrm{GT})^{30}$ & $\begin{array}{l}\text { F: ACGGTATGGAGTCAACTGC } \\
\text { R: CCCCTTTTGGTACATCATAG }\end{array}$ & $60{ }^{\circ} \mathrm{C}$ & AY322108 \\
\hline SaI19 & $(\mathrm{GT})^{25}$ & $\begin{array}{l}\text { F: ATTCTTCACAGGCCCAACACAAA R: } \\
\text { GAAAACACCGGCCCAGTACGA }\end{array}$ & $60^{\circ} \mathrm{C}$ & AY322111 \\
\hline SaI21 & $(\mathrm{GT})^{41}$ & $\begin{array}{l}\text { F: GGACGCCACACCATGTTCA } \\
\text { R: ACCGAAGCTGATTGTTAGTGTGA }\end{array}$ & $60{ }^{\circ} \mathrm{C}$ & AY322112 \\
\hline
\end{tabular}

\section{Data analysis}

Each microsatellite locus was scored in all D. sargus and D. vulgaris individuals using BioDocAnalyze 2.2 software (Biometra). Genetic diversity within sampling locations was measured by calculating the allele frequencies using GenAlEx 6.5 (Peakall and Smouse, 2012). Hardy-Weinberg values of the four examined microsatellite markers were tested by Chi square method, and other AMOVA tests was performed by ARLEQUIN v3.5 software (Excoffier and Lischer, 2010).

\section{RESULTS}

\section{Amplification of microsatellite loci in Diplodus sargus}

For all 56 samples of D. sargus isolated from Lake Burullus, Bahari, Abo Qir and Rashid, the presence of the microsatellite loci (SaI10, SaI12, SaI19 and SaI21) was determined by PCR reaction. The Genetic diversity within sampling locations was summarized in Table 2. The number of alleles per locus ranged from 3 to 19. The observed heterozygosity ranged from 0 (no heterozygosity) to 1 (for a system have a large number of equally frequent alleles). SaI19 locus had no heterozygosity in all populations which means that SaI19 locus had no genetic variability between populations. SaI10 locus had high heterozygosity in all populations that equals 1 in Lake Burullus. SaI12 locus had moderate to high genetic variability in Bahari, Abo Qir and Rashid but low genetic variability in Lake Burullus. SaI21 locus had low genetic variability in Abo Qir and Rashid but it had moderate genetic variability in Lake Burullus and Bahari. 
Table 2. Results of the amplification of four microsatellite loci (Sal10, Sal12, Sal19 and Sal21) in D. sargus from 4 different locations.

\begin{tabular}{|c|c|c|c|c|c|c|c|}
\hline $\begin{array}{l}\text { Sample } \\
\text { location* }\end{array}$ & Locus & $N$ & $\begin{array}{l}\text { Allele } \\
\text { range }\end{array}$ & size & $\begin{array}{ll}\text { No. of } \\
\text { alleles }\end{array}$ & $\boldsymbol{H}_{O}$ & $\boldsymbol{H}_{E}$ \\
\hline \multirow{4}{*}{ Lake Burullus } & SaI10 & 12 & $169-243$ & & 19 & 1.000 & 0.941 \\
\hline & SaI12 & 3 & $112-162$ & & 3 & 0.333 & 0.500 \\
\hline & SaI19 & 12 & $223-249$ & & 7 & 0.000 & 0.847 \\
\hline & SaI21 & 8 & $177-264$ & & 10 & 0.500 & 0.875 \\
\hline \multirow{4}{*}{ Bahari } & SaI10 & 13 & $164-286$ & & 19 & 0.846 & 0.938 \\
\hline & SaI12 & 5 & $112-207$ & & 7 & 0.800 & 0.840 \\
\hline & SaI19 & 14 & $223-271$ & & 10 & 0.000 & 0.878 \\
\hline & SaI21 & 10 & $282-186$ & & 15 & 0.600 & 0.925 \\
\hline \multirow{4}{*}{ Abo Qir } & SaI10 & 13 & $185-230$ & & 11 & 0.846 & 0.840 \\
\hline & SaI12 & 7 & 94-195 & & 10 & 0.571 & 0.888 \\
\hline & SaI19 & 14 & $241-265$ & & 4 & 0.000 & 0.704 \\
\hline & SaI21 & 8 & $72-226$ & & 10 & 0.250 & 0.891 \\
\hline \multirow{4}{*}{ Rashid } & SaI10 & 14 & $186-237$ & & 10 & 0.786 & 0.870 \\
\hline & SaI12 & 12 & $153-240$ & & 19 & 0.833 & 0.941 \\
\hline & SaI19 & 14 & $238-282$ & & 9 & 0.000 & 0.878 \\
\hline & SaI21 & 10 & $130-336$ & & 12 & 0.200 & 0.910 \\
\hline
\end{tabular}

$*=14$ individuals were used from four different locations (Lake Burullus, Bahari, Abo Qir and Rashid). $N=$ the number of successful samples, $H_{O}=$ observed heterozygosity, $H_{E}=$ Expected heterozygosity.

The analysis of molecular variance (AMOVA) showed little genetic differentiation among locations $\left(F_{s t}=0.048 ; P=0.001\right)$. Genetic variation in the studied populations was mainly due to individual variation within populations with a percentage of variance of 56\%. Individual-level variation among the population represented $39 \%$ of the variation while variation between populations was $5 \%$ (Table 3).

Table 3. Analysis of Molecular Variance (AMOVA) within and among D. sargus populations.

\begin{tabular}{|c|c|c|c|c|}
\hline $\begin{array}{l}\text { Source } \\
\text { variation }\end{array}$ & $\begin{array}{l}\text { Variance } \\
\text { component }\end{array}$ & $\begin{array}{l}\text { Percentage } \\
\text { of } \\
\text { variation } \\
\end{array}$ & Fixation indices & $\begin{array}{l}\text { Probability } \\
(P)\end{array}$ \\
\hline $\begin{array}{l}\text { Among } \\
\text { populations }\end{array}$ & 0.087 & $5 \%$ & $F_{s t}=0.048$ & 0.001 \\
\hline $\begin{array}{l}\text { Among individuals } \\
\text { within populations }\end{array}$ & 1.003 & $56 \%$ & $F_{i s}=0.590$ & 0.001 \\
\hline $\begin{array}{l}\text { Within } \\
\text { individuals among } \\
\text { all populations }\end{array}$ & 0.696 & $39 \%$ & $F_{i t}=0.610$ & 0.001 \\
\hline
\end{tabular}


Hardy-Weinberg values of the four examined microsatellite markers were shown in Table 4. Genotype frequencies at all four loci, except SaI12 locus, indicate an overall departure from Hardy-Weinberg expectations in two or more loci per location, which was attributed to the heterozygosity of the SaI19 and SaI21 loci. However, a significant HW values in all the populations were observed with the exception of the locus SaI21 in the Lake Burullus population. Hardy-Weinberg value of SaI12 locus was not significant in all populations, this means that SaI12 locus is in Hardy-Weinberg equilibrium.

Table 4. Hardy-Weinberg values (HW) of four microsatellite markers used in D. sargus isolated from 4 different locations.

\begin{tabular}{lllll}
\hline Locus & Lake Burullus & Bahari & Abo Qir & Rashid \\
\hline SaI10 & Ns & ns & 0.000 & 0.013 \\
\hline SaI12 & Ns & ns & ns & ns \\
\hline SaI19 & 0.000 & 0.000 & 0.000 & 0.000 \\
\hline SaI21 & Ns & 0.049 & 0.006 & 0.001
\end{tabular}

$\mathrm{ns}=$ not significant, significant value when $\mathrm{p}<0.05$.

\section{Amplification of microsatellite loci in Diplodus vulgaris}

The presence of the microsatellite loci (SaI10, SaI12, SaI19 and SaI21) were detected in 56 individuals of $D$. vulgaris from different locations including Lake Burullus, Bahari, Abo Qir and Rashid.

The Genetic diversity within sampling locations were summarized in Table 5. The number of alleles per locus ranged from 1 to 14 . The observed heterozygosity ranged from 0 to 0.857 .

SaI10 had moderate genetic variability in Lake Burullus population, low genetic variability in Bahari and no heterozygosity in both Abo Qir and Rashid. SaI12 had high genetic variability that reached 0.857 in Lake Burullus, moderate genetic variability in Bahari, low genetic variability in Abo Qir and no heterozygosity in Rashid. SaI19 locus had no heterozygosity in all populations which means that SaI19 locus had no genetic variability between populations. SaI21 had moderate genetic variability in Lake Burullus, low genetic variability in both Bahari and Abo Qir and High genetic variability in Rashid.

The results of molecular variance (AMOVA), was summarized in Table 6. Little genetic differentiation among locations were observed $\left(F_{s t}=0.048 ; P=0.001\right)$. Genetic variation in the studied fish was mainly due to the individual's variation within populations with a percentage of variance of $71 \%$. Individual-level variation (individual relative to all individuals) represented $21 \%$ of the variation while variation between populations (a population relative to other populations) was $8 \%$. 
Table 5. Results of the amplification of four microsatellite loci (SaI10, SaI12, SaI19 and SaI21) in D. Vulgaris.

\begin{tabular}{|c|c|c|c|c|c|c|}
\hline Sample location* & Locus & $N$ & $\begin{array}{l}\text { Allele size } \\
\text { range }\end{array}$ & $\begin{array}{ll}\text { No. } & \text { of } \\
\text { alleles } & \\
\end{array}$ & $\boldsymbol{H}_{O}$ & $\boldsymbol{H}_{E}$ \\
\hline \multirow{4}{*}{ Lake Burullus } & SaI10 & 14 & 153-199 & 7.000 & 0.500 & 0.753 \\
\hline & SaI12 & 7 & $100-163$ & 12.000 & 0.857 & 0.908 \\
\hline & SaI19 & 14 & $233-248$ & 8.000 & 0.000 & 0.837 \\
\hline & SaI21 & 7 & $154-246$ & 10.000 & 0.571 & 0.888 \\
\hline \multirow{4}{*}{ Bahari } & SaI10 & 14 & $168-223$ & 4.000 & 0.286 & 0.589 \\
\hline & SaI12 & 5 & $102-191$ & 7.000 & 0.600 & 0.840 \\
\hline & SaI19 & 14 & $238-260$ & 10.000 & 0.000 & 0.888 \\
\hline & SaI21 & 7 & 174-323 & 7.000 & 0.143 & 0.847 \\
\hline \multirow{4}{*}{ Abo Qir } & SaI10 & 14 & $239-265$ & 6.000 & 0.000 & 0.755 \\
\hline & SaI12 & 6 & 104-194 & 8.000 & 0.333 & 0.861 \\
\hline & SaI19 & 14 & 244-268 & 8.000 & 0.000 & 0.806 \\
\hline & SaI21 & 11 & $152-268$ & 14.000 & 0.364 & 0.921 \\
\hline \multirow{4}{*}{ Rashid } & SaI10 & 14 & $225-284$ & 6.000 & 0.000 & 0.806 \\
\hline & SaI12 & 1 & 182 & 1.000 & 0.000 & 0.000 \\
\hline & SaI19 & 14 & $223-282$ & 11.000 & 0.000 & 0.898 \\
\hline & SaI21 & 11 & $143-316$ & 17.000 & 0.727 & 0.930 \\
\hline
\end{tabular}

$*=14$ individuals were used from four different locations (Lake Burullus, Bahari, Abo Qir and Rashid). $N=$ the number of successful samples, $H_{O}=$ observed heterozygosity, $H_{E}=$ Expected heterozygosity.

Table 6. Analysis of Molecular Variance (AMOVA) within and among D. vulgaris populations.

\begin{tabular}{lcccc}
\hline Source of variation & Variance component & $\begin{array}{l}\text { Percentage } \\
\text { of } \\
\text { variation }\end{array}$ & $\begin{array}{l}\text { Fixation } \\
\text { indices }\end{array}$ & $\begin{array}{l}\text { Probability } \\
(\boldsymbol{P})\end{array}$ \\
\hline $\begin{array}{l}\text { Among populations } \\
\begin{array}{l}\text { Among individuals } \\
\text { within populations }\end{array}\end{array}$ & 0.133 & $8 \%$ & $F_{s t}=0.078$ & 0.001 \\
$\begin{array}{l}\text { Within individuals } \\
\text { among all } \\
\text { populations }\end{array}$ & 0.348 & $71 \%$ & $F_{i s}=0.776$ & 0.001 \\
\hline
\end{tabular}

Hardy-Weinberg values of the four examined microsatellite markers are shown in Table 7. An overall departure from Hardy-Weinberg expectations in two or more loci per locations was observed in the genotype frequencies at all four locations. This departure is due to a heterozygosity at SaI10, SaI19 loci that showed significant HW values in all populations. The HW expectations showed non-significant values in SaI12 locus of fish samples from Lake Burullus and Bahari. Meanwhile, SaI12 locus was monomorphic in fish species taken from Rashid (only one successfully amplified sample with one allele). SaI21 in Lake Burullus and Rashid populations showed non-significant values. 
Table 7. Hardy-Weinberg values (HW) of four microsatellite markers used in D. vulgaris isolated from 4 different locations.

\begin{tabular}{lllll}
\hline Locus & Lake Burullus & Bahari & Abo Qir & Rashid \\
\hline SaI10 & 0.045 & 0.002 & 0 & 0 \\
SaI12 & ns & ns & 0.043 & Monomorphic \\
SaI19 & 0 & 0 & 0 & 0 \\
SaI21 & ns & 0.023 & 0.003 & ns \\
\hline
\end{tabular}

$\mathrm{ns}=$ not significant, significant value means $\mathrm{p}<0.05$.

\section{DISCUSSION}

The genotype data collected on $D$. sargus and $D$. vulgaris from the four geographical sites (Lake Burullus, Bahari, Abo Qir and Rashid) indicate sharing of the genetic material among populations as the $F_{s t}$ value $=0.048$ in D. sargus and 0.078 in D. vulgaris. Roques et al. (2007) used nine microsatellite markers for $D$. vulgaris to test the cross-species amplification in D. sargus and Oblada melanura. Their results indicated that there were close phylogenetic relationships between the three species which agreed with our results.

In the present study, all loci were polymorphic in two species of the four populations except SaI12 locus in Rashid populations when examined in D. vulgaris. Greater variation was seen within $D$. sargus than that of $D$. vulgaris. In other studies a high levels of polymorphism was observed in microsatellite loci of $D$. sargus and $D$. vulgaris species which is persistent with the mean allele number observed in Sparidae fish species (Brown et al., 2005; Liu et al., 2007; González-wangüemert et al., 2010).

The large observed divergence of the observed $\left(H_{O}\right)$ from the expected $\left(H_{E}\right)$ heterozygosity, and also low number of successful amplified samples at some loci may indicate the need for further PCR optimization in some cases. However, locus SaI10 (in all locations) in D. sargus, SaI19 in D. sargus and D. vulgaris and SaI21 in D. vulgaris showed encouraging results for the likely use of these loci in the microsatellite examinations.

SaI10 locus showed low heterozygosity in $D$. sargus and high heterozygosity in $D$. vulgaris which agreed with the results of Brown et al. (2005) who found that SaI10 locus showed high heterozygosity in Pagrus pagrus, Dentex dentex and Spondyliosoma cantharus. These results also agreed with Liu et al. (2007) who found that SaI10 locus showed high heterozygosity in Acanthopagrus schlegeli.

SaI12 locus showed low heterozygosity in Lake Burullus population of D. sargus (0.333), and in D. vulgaris populations of both Abo Qir and Rashid populations reaching 0 (no heterozygosity) These results are in harmony with the results of Brown et al. (2005) who found that SaI12 locus showed no heterozygosity in D. sargus.

SaI19 locus showed no heterozygosity in all locations in both $D$. sargus and $D$. vulgaris. These results contradicts the findings of Brown et al. (2005) who found that this locus showed high heterozygosity in D. sargus, Pagrus pagrus and Dentex dentex. Similarly, Liu et al. (2007) found that SaI19 locus exhibited high heterozygosity in Acanthopagrus schlegeli.

In our results, SaI21 locus showed successful amplification in both D. sargus and $D$. vulgaris. These results disagree with those of Brown et al. (2005) who reported a failure 
of amplification of SaI21 microsatellite locus in some species of family Sparidae including $D$. sargus and $D$. vulgaris.

In the present study, the analysed populations of both fishes showed some variability in the values of the observed heterozygosity of the microsatellite loci (ranged from 0 to 1 in D. sargus and from 0 to 0.857 in D. vulgaris). Meanwhile the expected heterozygosity showed high values in both $D$. sargus ( 0.5 to 0.95 ) and $D$. vulgaris ( 0.75 to 0.93 ), similar to or slightly lower than that observed for marine fish that varied between 0.84 and 0.92 as reviewed by Carvalho and Hauser (1998).

The levels of genetic variability observed in $D$. sargus and D. vulgaris were lower than those in other Sparidae fishes assessed with microsatellites markers $(0.048$ in $D$. sargus and 0.078 in D. vulgaris in this work). Meanwhile, levels in Pagrus major was 0.69, in Acanthopagrus schlegeli was $0.55-0.95$ and in Pagellus bogaraveo was 0.72 (Perez-Enriquez and Taniguchi, 1999; Liu et al., 2007; Piñera et al., 2007). Similarly, González-Wangüemert et al. (2010) found that similar genetic diversity and nonsignificant genetic differences of white seabream (Diplodus sargus) were recorded at Mediterranean islands in the vicinity of continental samples. He also suggested that proximity of the coasts and the current system could contribute to an optimal fish larval dispersion among Mediterranean coasts with high gene flow.

\section{CONCLUSION}

Three microsatellite loci (SaI10, SaI12, and SaI21) isolated from S. aurata can be applicable in D. sargus and D. vulgaris. SaI10 and SaI21 in D. sargus and D. vulgaris respectively and could also be used for the examination of their presence in other species of family Sparidae. These cross-amplified markers showed a statistical power that can be used in the analysis performed in this study as much as it has been used in S. aurata.

In terms of population subdivision in the 4 geographical regions in the Mediterranean Sea in Egypt, the results showed no significant genetic differentiation throughout the four studied locations. The cause of the lower observed heterozygosity compared to the expected heterozygosity in both $D$. sargus and $D$. vulgaris populations may be due to inbreeding. The shared genetic material in the studied region of the Mediterranean Sea could be explained by the free movement of the fish along the area.

\section{ACKNOWLEDGEMENT}

This research was financed by The Science Technology Development Fund (STDF; Project ID: 5609), Ministry of High Education and Scientific research, to whom I am very grateful.

We would also like express my special thanks to Dr. Taha Soliman; associate professor of Genetics and Genetic engineering at National Institute of Oceanography and Fisheries, for his help in the selection of the microsatellite markers.

We would like to thank Dr. Mohamed Tawfic; professor at Suez Canal University for his proof reading and English editing. 


\section{REFERENCES}

Abbas, E. M.; Megahed, E. T.; Hemeda, S. and El-nahas, A. (2018). DNA barcoding and molecular population structure of two species from genus Diplodus based on COI gene in the Egyptian Mediterranean Sea DNA barcoding and molecular population structure of two species from genus Diplodus based on COI gene in the Egyptian M. Int. J. Fish. Aquat. Stud. 6(1): 1-8.

Abbas, E. M.; Soliman, T., El-Magd; M. A., Farrag, M. M. S.; Ismail, R. F. and Kato, M. (2017). Phylogeny and DNA barcoding of the family Sparidae inferred from mitochondrial DNA of the Egyptian waters. J. Fish. Aquat. Sci. 2: 73-81. doi:10.3923/jfas.2017.

Alarcón, J. A. and Alvarez, M. C. (1999). Genetic identification of sparid species by isozyme markers: application to interspecific hybrids. Aquaculture 173: 95-103. doi:10.1016/S0044-8486(98)00473-6.

Ali, B. A.; Ahmed, M. M. M. and El-Zaeem, S. Y. (2004). Technical note: application of RAPD markers in fish. Part II: among and within families; Cichlidae (Freshwater), Mugilidae (Catadromous), Sparidae and Serranidae (Marine). Int. J. Biotechnol. 6(4): 393-401. doi:10.1504/IJBT.2004.005522.

Armani, A.; Guardone, L.; Castigliego, L.; D’Amico, P.; Messina, A.; Malandra, R., et al. (2015). DNA and Mini-DNA barcoding for the identification of Porgies species (family Sparidae) of commercial interest on the international market. Food Control 50: 589-596. doi:10.1016/j.foodcont.2014.09.025.

Bianchi, C. N. and Morri, C. (2000). Marine Biodiversity of the Med SEA. Mar. Pollut. Bull. 40(5): 367-376. doi:10.1016/S0025-326X(00)00027-8.

Brown, R. C.; Tsalavouta, M.; Terzoglou, V.; Magoulas, A. and Mcandrew, B. (2005). Additional microsatellites for Sparus aurata and cross-species amplification within the Sparidae family. Mol. Ecol. Notes 5: 605-607. doi:10.1111/j.14718286.2005.01007.x.

Carvalho, G. R. and Hauser, L. (1998). Advances in the molecular analysis of fish population structure. Ital. J. Zool. 65(1): 21-33. doi:10.1080/11250009809386791.

Casu, M.; Lai, T.; Curini-Galletti, M.; Ruiu, A. and Pais, A. (2009). Identification of Mediterranean Diplodus spp. and Dentex dentex (Sparidae) by means of DNA InterSimple Sequence Repeat (ISSR) markers. J. Exp. Mar. Bio. Ecol. 368(2): 147-152. doi:10.1016/j.jembe.2008.09.021.

Cocolin, L.; D’Agaro, E.; Manzano, M.; Lanari, D. and Comi, G. (2000). Rapid PCRRFLP method for the identification of marine fish fillets (seabass, seabream, umbrine, and dentex). J. Food Sci. 65: 1315-1317. doi:10.1111/j.13652621.2000.tb10604.x.

Cooke, G. M.; Schlub, T. E.; Sherwin, W. B. and Ord, T. J. (2016). Understanding the spatial scale of genetic connectivity at sea: Unique insights from a land fish and a meta-analysis. PLoS One 11(5): 1-25. doi:10.1371/journal.pone.0150991.

Cseke, L. J.; Jirakosyan, A.; Kaufman, P. B. and westfall, M. V (2011). Molecular and Cellular Methods in Biology and Medicine. 3rd ed. New York: CRC Press.

El-deeb, S. I.; El-seedy, A. S.; Abdel, A., Abo, M. and El-wakeel, H. E. (2014). Genetic divergence and phylogenetic relationship among five sparid species from the coastal 
waters of Egypt. Life Sci. J. 11: 779-789.

Excoffier, L. and Lischer, H. E. L. (2010). Arlequin suite ver 3.5. Mol. Ecol. Resour. 10: 564-567.

Fan, H. and Gulley, M. L. (2001). DNA extraction from fresh or frozen tissues. Methods Mol. Med. 49: 11-14. doi:10.1385/1-59259-081-0:11.

Fernández, I.; Moyano, F. J.; Díaz, M. and Martínez, T. (2001). Characterization of $\alpha-$ amylase activity in five species of mediterranean sparid fishes (sparidae, teleostei). J. Exp. Mar. Bio. Ecol. 262(1): 1-12. doi:10.1016/S0022-0981(01)00228-3.

Field, D. and Wills, C. (1996). Long, Polymorphic Microsatellites in Simple Organisms. 209-215. doi:10.1098/rspb.1996.0033.

Fischer, W.; Bauchot, M. L. and Schneider, M. (1987). Fiches FAO d'identification des espèces pour le besoins de la pêche (Révision 1). Zone de pêche.

Fishbase (2016). A global information system on fishes. Available at: www.fishbase.org.

Garcia, A. and Macpherson, E. (1995). Substrate use and temporal pattern of recruitment in juvenile fishes of the Mediterranean littoral. Mar. Biol., 124: 35-42. doi:https://doi.org/10.1007/BF00349144.

González-wangüemert, M.; Cánovas, F.; Pérez-ruzafa, A.; Marcos, C. and Alexandrino, P. (2010). Connectivity patterns inferred from the genetic structure of white seabream (Diplodus sargus L.). J. Exp. Mar. Bio. Ecol. 383(1): 23-31. doi:10.1016/j.jembe.2009.10.010.

González-wangüemert, M.; Froufe, E. and Pérez-ruzafa, A. (2011). Phylogeographical history of the white seabream Diplodus sargus (Sparidae): implications for insularity. Mar. Biol. Res. 7(3): 250-260. doi:10.1080/17451000.2010.499438.

González-Wangüemert, M.; Pérez-Ruzafa, Á.; Cánovas, F.; García-Charton, J. A. and Marcos, C. (2007). Temporal genetic variation in populations of Diplodus sargus from the SW Mediterranean Sea. Mar. Ecol. Prog. Ser. 334: 237-244. doi:10.3354/meps334237.

González-Wangüemert, M.; Pérez-Ruzafa, Á.; Marcos, C. and García-Charton, J. A. (2004). Genetic differentiation of Diplodus sargus (Pisces: Sparidae) populations in the south-west Mediterranean. Biol. J. Linn. Soc. 82(2): 249-261. doi:10.1111/j.1095-8312.2004.00356.x.

Kaouèche, M.; Bahri-Sfar, L.; González-Wangüemert, M.; Pérez-Ruzafa, 'A. and Hassine, O. Ben (2011). Allozyme and mtDNA variation of white seabream Diplodus sargus populations in a transition area between western and eastern Mediterranean basins. African J. Mar. Sci. 33(1): 79-90. doi:10.2989/1814232X.2011.572342.

Liu, Y.; Liu, L.; Wu, Z.; Lin, H.; Li, B. and Sun, X. (2007). Isolation and characterization of polymorphic microsatellite loci in black sea bream ( Acanthopagrus schlegeli ) by cross-species amplification with six species of the Sparidae family. Aquat. Living Resour. 20: 257-262. doi:10.1051/alr:2007038.

Lloret, J. and Planes, S. (2003). Condition, feeding and reproductive potential of white seabream Diplodus sargus as indicators of habitat quality and the effect of reserve protection in the northwestern Mediterranean. Mar. Ecol. Prog. Ser., 248: 197-208. doi: $10.3354 /$ meps 248197.

Macpherson, E. (1998). Ontogenetic shifts in habitat use and aggregation in juvenile sparid fishes. 220: 127-150. doi:10.1016/S0022-0981(97)00086-5.

Macpherson, E.; Biagi, F.; Francour, P.; García-Rubies, A.; Harmelin, J.; Harmelin- 
vivien, M., et al. (1997). Mortality of juvenile fishes of the genus Diplodus in protected and unprotected areas in the western Mediterranean Sea. Mar. Ecol. Prog. Ser., 160: 135-147. doi:10.3354/meps160135.

Morato, T.; Afonso, P.; Lourinho, P.; Nash, R. D. M. and Santos, R. S. (2003). Reproductive biology and recruitment of the white sea bream in the Azores. J. Fish Biol., 59-72. doi:10.1046/j.1095-8649.2003.00129.x.

Pajuelo, B. J. G. and Lorenzo, J. M. (2004). Basic characteristics of the population dynamic and state of exploitation of Moroccan white seabream Diplodus sargus cadenati ( Sparidae ) in the Canarian archipelago. J. Appl. Ichthyol., 20: 15-21. doi:10.1046/j.0175-8659.2003.00540.x.

Peakall, R. and Smouse, P. E. (2012). GENALEX 6.5: Genetic analysis in Excel. Population genetic software for teaching and research. Mol. Ecol. Notes, 28: 25372539. doi:10.1111/j.1471-8286.2005.01155.x.

Perez-Enriquez, R. and Taniguchi, N. (1999). Genetic structure of red sea bream (Pagrus major) population off Japan and the Southwest Pacific, using microsatellite DNA markers. Fish. Sci. 65(1): 23-30. doi:10.2331/fishsci.65.23.

Pérez-Ruzafa, Á.; González-Wangüemert, M.; Lenfant, P.; Marcos, C. and GarcíaCharton, J. A. (2006). Effects of fishing protection on the genetic structure of fish populations. Biol. Conserv. 129(2): 244-255. doi:10.1016/j.biocon.2005.10.040.

Pérez, L.; Infante, C.; Ponce, M.; Crespo, A.; Zuasti, E.; Funes, V., et al. (2008). Characterization of eight microsatellite markers in the white sea bream, Diplodus sargus (Teleostei, Sparidae). Mol. Ecol. Resour. 8(6): 1291-1293. doi:10.1111/j.1755-0998.2008.02173.x.

Piñera, J. A.; Blanco, G.; Vázquez, E. and Sánchez, J. A. (2007). Genetic diversity of blackspot seabream (Pagellus bogaraveo) populations ov Spanish coasts: A preliminary study. Mar. Biol. 151: 2153-2158. doi:10.1007/s00227-007-0665-5.

Planes, S.; Hertel, O. and Jouvenel, J. (1997). Analysis Of Condition and Swimming Performance in Juveniles of White Sea Bream, Diplodus Vulgaris. J. Mar. Biol. Assoc. United Kingdom, 77: 913-916. doi:10.1017/S0025315400036298.

Planes, S. and Lenfant, P. (1996). Genetic differentiation of white sea bream within the Lion's Gulf and the Ligurian Sea ( Mediterranean Sea ). J. Fish Biol. 49: 613-621. doi:10.1111/j.1095-8649.1996.tb00058.x.

Roques, S.; Galarza, J. A.; Macpherson, E.; Turner, G. F. and Rico, C. (2007). Isolation and characterization of nine polymorphic microsatellite markers in the two-banded sea bream (Diplodus vulgaris) and cross-species amplification in the white sea bream (Diplodus sargus) and the saddled bream (Oblada melanura). Mol. Ecol. Notes 7(4): 661-663. doi:10.1111/j.1471-8286.2006.01667.x.

Rosecchi, E. (1987). The feeding of Diplodus annularis, Diplodus sargus, Diplodus vulgaris and Sparus aurata (Pisces, Sparidae) in the Lion Gulf and the coastal lagoons. Rev. des Trav. l'Institut des pêches Marit., 49: 125-141.

Schiefenhövel, K. and Rehbein, H. (2013). Differentiation of Sparidae species by DNA sequence analysis, PCR-SSCP and IEF of sarcoplasmic proteins. Food Chem. 138(1): 154-160. doi:10.1016/j.foodchem.2012.10.057.

Surzycki, S. (2000). Basic techniques in molecular biology.

Vigliola, L. and Harmelin-Vivien, M. (2001). Post-settlement ontogeny in three Mediterranean reef fish species of the genus Diplodus. Bull. Mar. Sci. 68: 271-286. 
Whitehead, P. J. P.; Bauchot, M. L.; Hureau, J. C.; Nielsen, J. and Tortonese, E. (1986). Fishes of the north-eastern Atlantic and the Mediterranean. United Nations Educational Scientific and Cultural Organization.

Zander, C. D. and Sötje, I. (2002). Seasonal and geographical differences in cleaner fish activity in the Mediterranean Sea. Helgol. Mar. Res., 55: 232-241. doi:10.1007/s101520100084.

Zhou, C.; Wu, C. W.; Guo, B. Y. and Chen, Y. J. (2015). Genetic diversity in ribosomal $18 \mathrm{~S}$ rRNA and mitochondrial COIII genes in Chinese cultured populations of mussel Mytilus galloprovincialis. Biochem. Syst. Ecol., 59: 135-143.

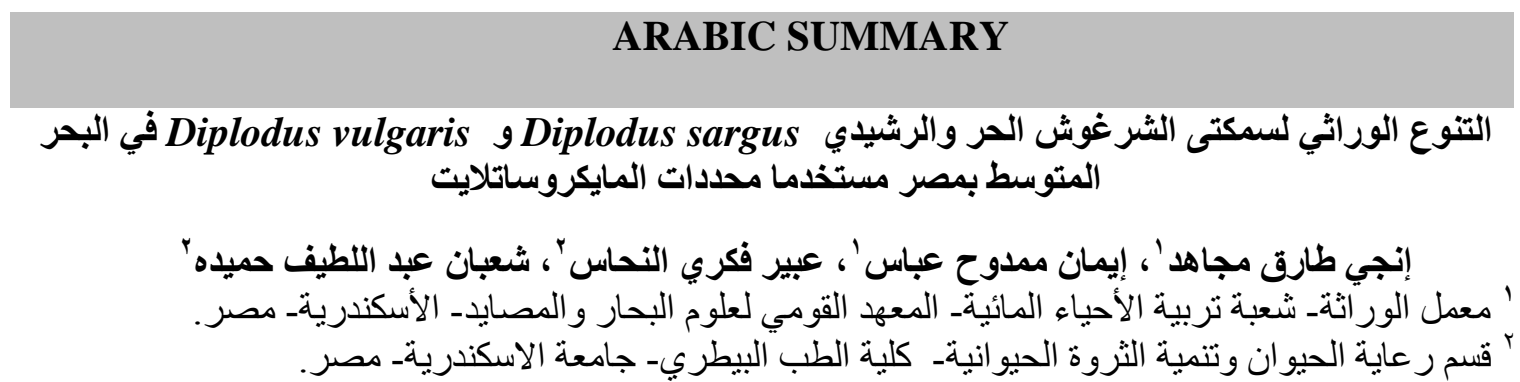

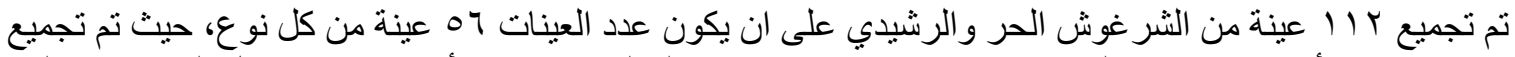

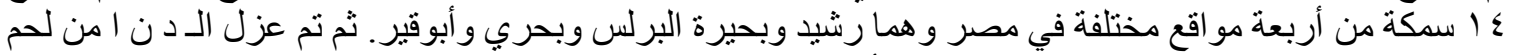

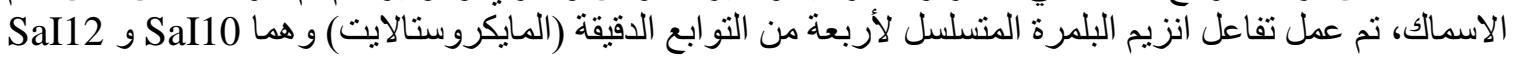
و SaI19 و SaI21 في كل من الثرغ غوش الحر و الرشيدي.

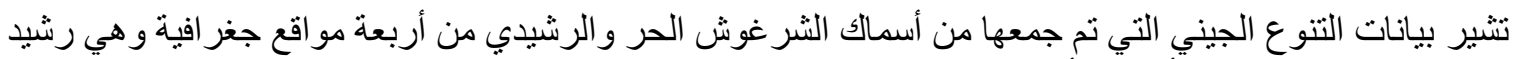

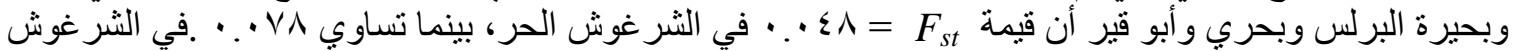

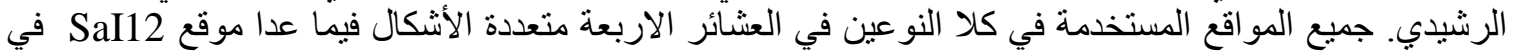

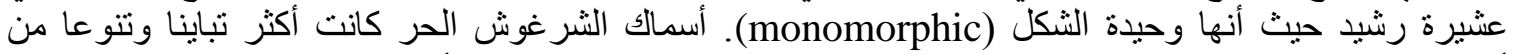

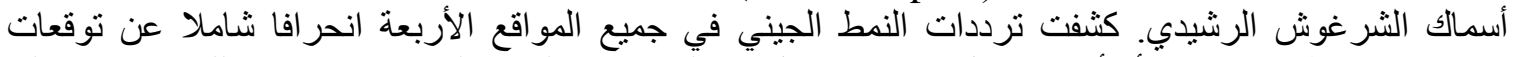

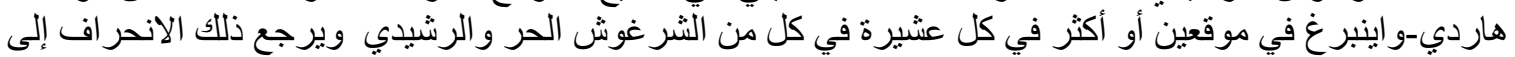

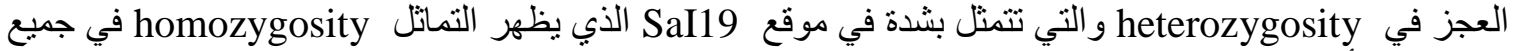
العشائر في أسماك الثر غوش الحر و الرشيدي.

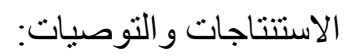

أن الاربعة توابع دقيقة المستخدمة في هذه الدراسة قادرة على تعريف اسماك الثر غوش الحر والرشيدي

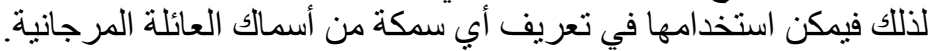

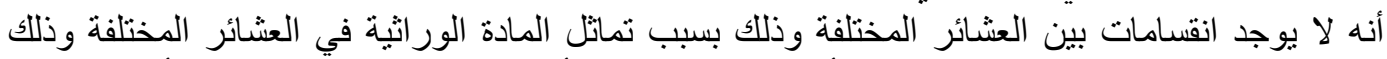
يرجع إلى غياب الحدود البحرية للبحر الأبيض المنوسط كما أنه يرجع إلى سرعة حركة الأسماك خلال

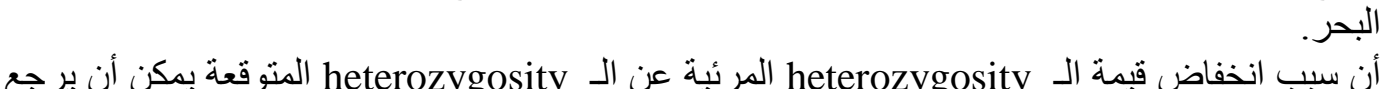

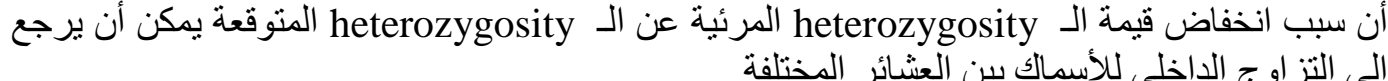

